\title{
TNFR1 and TNFR2 regulate the extrinsic apoptotic pathway in myeloma cells by multiple mechanisms
}

\author{
H Rauert ${ }^{1}$, T Stühmer ${ }^{2}$, R Bargoư ${ }^{2}$, H Wajant ${ }^{\star, 1}$ and D Siegmund ${ }^{1}$
}

The huge majority of myeloma cell lines express TNFR2 while a substantial subset of them failed to show TNFR1 expression. Stimulation of TNFR1 in the TNFR1-expressing subset of MM cell lines had no or only a very mild effect on cellular viability. Surprisingly, however, TNF stimulation enhanced cell death induction by CD95L and attenuated the apoptotic effect of TRAIL. The contrasting regulation of TRAIL- and CD95L-induced cell death by TNF could be traced back to the concomitant NF $k \mathrm{~B}$ mediated upregulation of CD95 and the antiapoptotic FLIP protein. It appeared that CD95 induction, due to its strength, overcompensated a rather moderate upregulation of FLIP so that the net effect of TNF-induced NF $\kappa$ B activation in the context of CD95 signaling is pro-apoptotic. TRAIL-induced cell death, however, was antagonized in response to TNF because in this context only the induction of FLIP is relevant. Stimulation of TNFR2 in myeloma cells leads to TRAF2 depletion. In line with this, we observed cell death induction in TNFR1-TNFR2-costimulated JJN3 cells. Our studies revealed that the TNF-TNF receptor system adjusts the responsiveness of the extrinsic apoptotic pathway in myeloma cells by multiple mechanisms that generate a highly context-dependent net effect on myeloma cell survival.

Cell Death and Disease (2011) 2, e194; doi:10.1038/cddis.2011.78; published online 18 August 2011

Subject Category: Experimental Medicine

Multiple myeloma is the consequence of malignant transformation of terminally differentiated antibody producing B-cells. Myeloma cells predominantly reside in the bone marrow where they trigger the formation of an osteoclastic microenvironment, eventually leading to bone destruction and associated therewith displacement of normal hematopoiesis. ${ }^{1,2}$ Two seminal studies demonstrated that about $80 \%$ of primary myeloma samples display a gene expression signature characteristic of transcription factors of the nuclear factor $\kappa \mathrm{B}\left(\mathrm{NF}_{\kappa} \mathrm{B}\right)$ family, and identified mutations indicative for cell autonomous activation of $\mathrm{NF} \kappa \mathrm{B}$ signaling in about $20 \%$ of myeloma cases. ${ }^{3,4} \mathrm{NF} \kappa \mathrm{Bs}$ act as homo- or heterodimers and accomplish pivotal functions in development, cell growth, cell survival and particularly in immune regulation. The activity of $\mathrm{NF} \kappa \mathrm{B}$ transcription factors is held in check by intermolecular interaction with inhibitor of $\kappa \mathrm{B}\left(\mathrm{l}_{\kappa} \mathrm{B}\right)$ proteins or by intramolecular interaction with an $1 \kappa$ B-related domain both resulting in masking of the nuclear localization sequence of $\mathrm{NF}_{\kappa} \mathrm{Bs}$. $^{5,6}$ Inducible proteolysis/processing of $\mathrm{I}_{\kappa} \mathrm{B}$ proteins (or $\mathrm{I}_{\kappa} \mathrm{B}$-like domains) thus represents the central bottleneck in $\mathrm{NF}_{\kappa} \mathrm{B}$ activation. It takes place by two distinct routes: the classical (canonical) and the alternative (non-canonical) $\mathrm{NF}_{\kappa} \mathrm{B}$ pathway. ${ }^{5,6}$ In the classical pathway, receptor induced activation of E3 ligases of the TNF receptor-associated factor (TRAF) family and TRAF-associated kinases trigger activation of the
$\mathrm{I} \kappa \mathrm{B}$ kinase (IKK) complex. The latter in turn entails ubiquitination and subsequent degradation of $I \kappa B$ proteins. ${ }^{5,6}$ In contrast, activation of the alternative $\mathrm{NF}_{\kappa} \mathrm{B}$ signaling pathway is independent of the IKK complex and instead relies on receptor-induced deviation/degradation of TRAF2 and TRAF3. The latter two in concert with clAP1/2 are responsible for constitutive degradation of the MAP3K NIK. ${ }^{5,6}$ Receptorinduced degradation of TRAF2 and TRAF3 thus results in NIK accumulation. NIK in turn stimulates the IKK1 kinase, which then phosphorylates $\mathrm{p} 100$, the precursor of the NF $\kappa$ B family member p52 which contains an $\mid \kappa B$-like inhibitory domain. Phosphorylation of $\mathrm{p} 100$ results in proteasomal destruction of the inhibitory domain by limited processing of the molecule resulting in active p52-containing $\mathrm{NF}_{\kappa} \mathrm{Bs}^{5,6}$ The classical $\mathrm{NF} \kappa \mathrm{B}$ pathway is stimulated by a wide variety of cellular stressors (e.g. PAMPs, UV and irradiation) and members of the Toll-like and the TNF receptor families. One of the strongest, best investigated and most widely distributed activators of the classical $\mathrm{NF}_{\kappa} \mathrm{B}$ pathway is $\mathrm{TNFR}_{1 .}{ }^{7}$ In contrast to the classical $\mathrm{NF}_{\kappa} \mathrm{B}$ pathway, the alternative $\mathrm{NF}_{\kappa} \mathrm{B}$ pathway is stimulated by a rather limited set of inducers most of which belong to the TNF receptor family. 5,6 Notably, TNFR2, the second receptor of TNF is a comparably weak trigger of classical $\mathrm{NF}_{\kappa} \mathrm{B}$ signaling but is able to induce the alternative $\mathrm{NF}_{\kappa} \mathrm{B}$ pathway. ${ }^{8} \mathrm{TNF}$, like most other members of

\footnotetext{
${ }^{1}$ Division of Molecular Internal Medicine, Department of Internal Medicine II, University Hospital Würzburg, Würzburg, Germany and ${ }^{2}$ Comprehensive Cancer Center Mainfranken and Department of Internal Medicine II, Division of Hematology, University Hospital Würzburg, Würzburg, Germany

${ }^{*}$ Corresponding author: H Wajant, Division of Molecular Internal Medicine, Department of Internal Medicine II, University Hospital Würzburg, Röntgenring 11, 97070 Würzburg, Germany. Tel: + 49 (931) 201 71010; Fax: + 49 (931) 201 71070; E-mail: harald.wajant@ mail.uni-wuerzburg.de Keywords: apoptosis; CD95; multiple myeloma; NF $\kappa \mathrm{B}$; TNF; TRAIL

Abbreviations: FACS, fluorescence-activated cell sorting; FBS, fetal bovine serum; CIAP1/2, cellular inhibitor of apoptosis protein-1/2; $l_{\kappa} \mathrm{B} \alpha$, inhibitor of kappa B-alpha; $\mathrm{NF} \kappa \mathrm{B}$, nuclear factor kappa B; NIK, NF $\kappa$ B inducing kinase; PBS, phosphate-buffered saline; SDS-PAGE, sodium dodecyl sulfate polyacrylamide gel electrophoresis; TNF, tumor necrosis factor; TNFR1/2, TNF receptor-1/2; TRAF1/2, TNF receptor-associated factor-1/2; TPCA-1, (2-((aminocarbonyl)amino)-5-(4-fluorophenyl)-3thiophenecarboxamide); TRAIL, TNF-related apoptosis inducing ligand; TRAILR1/2, TRAIL receptor-1/2; zVAD, benzyloxycarbonyl-Val-Ala-Asp (OMe) fluoromethylketone.
}

Received 04.7.11; accepted 14.7.11; Edited by G Melino 
the TNF ligand family, is a homotrimeric type II transmembrane protein from which soluble trimers can be released by proteolytic processing. ${ }^{9}$ It is worth mentioning that both TNF receptors are robustly activated by membrane TNF while soluble TNF predominantly stimulates TNFR1 despite binding to TNFR2. ${ }^{9}$ Thus, the availability of TNFR1, TNFR2 and of soluble and membrane TNF in sum determines the activity of the classical and alternative pathway in situations of TNF exposure.

In view of the relevance of the $\mathrm{NF}_{\kappa} \mathrm{B}$ system for myeloma cells and the fact that $\mathrm{NF}_{\kappa} \mathrm{Bs}$ regulate a variety of survival genes, we investigated in this study whether and how TNF and its receptors regulate the apoptotic sensitivity of myeloma cells.

\section{Results}

TNF receptor expression in multiple myeloma. FACS analysis showed that with exception of U266 all investigated myeloma cell lines express TNFR2 on their cell surface (Figure 1a). Cell surface expression of TNFR1 was more heterogeneous yielding clear staining only in 3 out of 10 cell lines (MM.1S, RPMI8226 and KMS-12-BM; Figure 1a). Using a highly sensitive ligand-binding assay with a Gaussia princeps luciferase fusion protein of the TNFR1-specific TNF mutant $32 \mathrm{~W} / 86 \mathrm{~T},{ }^{10}$ we were able to detect significant TNFR1 expression in five additional cell lines (U266, OPM2, KMS-11, INA6 and JJN3) while even with this assay there was no evidence for TNFR1 expression in AMO1 and L363 (Figure 1b). Binding studies with a Gaussia princeps luciferase fusion protein of the TNFR2-specific TNF mutant $143 \mathrm{~N} / 145 \mathrm{R}^{10}$ confirmed the lack of TNFR2 expression in U266 cells as well as expression of this receptor on all the other cell lines (Figure 1b). In the three cell lines where TNFR1 expression was already evident by FACS analysis and also in two of the four cell lines (OPM2 and INA6) where TNFR1 expression was only evident by the more sensitive binding studies, stimulation with TNFR1-specific Flag$\mathrm{TNF}(32 \mathrm{~W} / 86 \mathrm{~T})$ resulted in robust activation of the classical $\mathrm{NF} \kappa \mathrm{B}$ pathway in terms of phosphorylation and degradation of $I_{\kappa} \mathrm{B} \alpha$. Albeit very weak, there was also in half of the cell lines activation of the classical $\mathrm{NF}_{\kappa} \mathrm{B}$ pathway upon stimulation with a non-americ form of the TNFR2-specific TNF mutant $143 \mathrm{~N} / 145 \mathrm{R}$ that mimics the activity of membrane TNF on this receptor (Figure 2a). ${ }^{8}$ Indeed, while induction of $\mathrm{NF} \kappa \mathrm{B}$-regulated factors such as RelB, TRAF1 and p100 was readily observable in western blot analysis of TNFR1-stimulated cells, only one of five analyzed cell lines showed a corresponding TNFR2-induced response (Figure 2b). The lower or even missing capability of TNFR2 to trigger the classical $\mathrm{NF}_{\kappa} \mathrm{B}$ pathway corresponds to former reports demonstrating that TNFR1 is superior to TNFR2 in activation of this response and that the latter depends on the presence of the highly regulated TRAF1 protein to elicit an optimal response. 8,11

TNF differentially regulates TRAIL- and CD95L-induced cell death in myeloma cells. A major effect of activation of transcription factors of the $\mathrm{NF} \kappa \mathrm{B}$ family is the transcriptional upregulation of survival genes. ${ }^{12}$ To reveal a potential protective effect of TNFR1-mediated $\mathrm{NF}_{\kappa} \mathrm{B}$ activation on myeloma cells, we primed the three highly TNFR1 responsive myeloma cell lines identified above (MM.1S, RPMI8226 and KMS-12-BM) with soluble TNF and challenged the cells then for $24 \mathrm{~h}$ with TRAIL and CD95L that stimulate the death receptors TRAILR1, TRAILR2 and CD95 as well as with bortezomib (proteasome inhibitor), NVP-AUY922 (HSP90 inhibitor) and the Akt inhibitor Akti-1/2. Stimulation of the death receptor TNFR1 alone led to no or only marginal cell death (Figure $3 \mathrm{a}$ ), whereas exclusive stimulation with either TRAIL or CD95L resulted in almost complete killing of myeloma cells (Figures $3 b$ and $c$ ). Priming of myeloma cells with TNF had no or only a marginal effect on cell death-induction by the three pharmacological inhibitors suggesting that activation of the classical NF $\kappa \mathrm{B}$ pathway does not interfere with the anti-myeloma effect of these clinical and preclinical drugs. TNF priming, however, exerted opposing effects on TRAIL- and CD95L-induced cell death of MM.1S and RPMI8226 cells (Figures $3 c$ and d). In these cell lines there was a strong enhancement of CD95Linduced cell death upon TNF priming while TRAIL-induced cell death was reduced (Figures $3 c$ and $d$ ). In the third cell line, KMS-12-BM, there was a moderate sensitizing effect of TNF on both TRAIL- and CD95L-induced cell death (Figure 3b). Because CD95 and the TRAIL death receptors utilize the same receptor-associated mechanisms to induce cell death, ${ }^{13}$ the opposing modulation of their cytotoxic effects by TNF observed in MM.1S and RPMI8226 cells was surprising and therefore investigated in more detail.

TNF sensitizes myeloma cells for CD95L-induced cell death by TNFR1-induced IKK2-mediated upregulation of CD95. CD95 and the TRAIL death receptors trigger cell death not only via caspase-8-mediated activation of the intrinsic apoptotic pathway, but also by the virtue of caspase8 activity-independent induction of necrosis via the receptorassociated serine/threonine kinase RIP1. ${ }^{14}$ We therefore proved first whether CD95L and TRAIL utilize the same molecular mechanisms to initiate MM cell death by help of the caspase inhibitor zVAD and the RIP1 inhibitor necrostatin-1. Treatment with the caspase inhibitor zVAD alone was fully sufficient to rescue MM.1S cells from TRAILand CD95L-induced cell death, irrespective of TNF priming (Figure $4 \mathrm{a}$ ). In the case of RPMI8226 cells, zVAD treatment only partly rescued cells from death ligand-induced apoptosis. Addition of necrostatin-1 further improved the protective effect of ZVAD in RPMI8226 cells indicating that these cells principally respond with apoptosis and with necrosis toward death receptor activation (Figure 4a). Again TNF priming showed no effect on the quality of cell death induced by TRAIL and CD95L, making it unlikely that the differential effect of TNF priming is related to the utilization of different death pathways by CD95 and the TRAIL death receptors. An important receptor proximal factor determining cellular sensitivity for the extrinsic pathway is cell surface expression of the death receptors. FACS analysis showed no significant changes in TRAIL receptor expression but revealed a pronounced upregulation of cell surfaceexpressed CD95 in the TNF-primed cells (Figure 4b). 
a

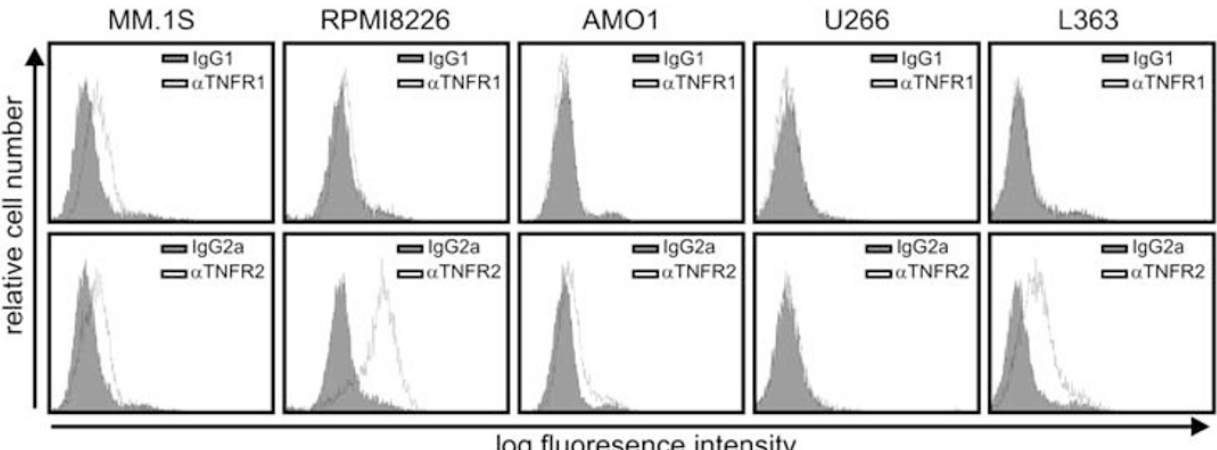

log fluoresence intensity

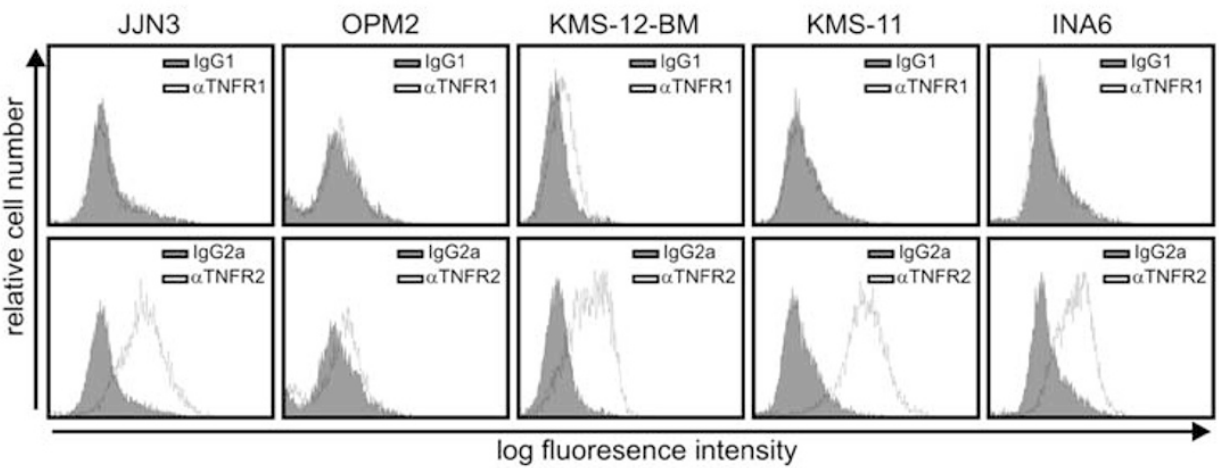

b
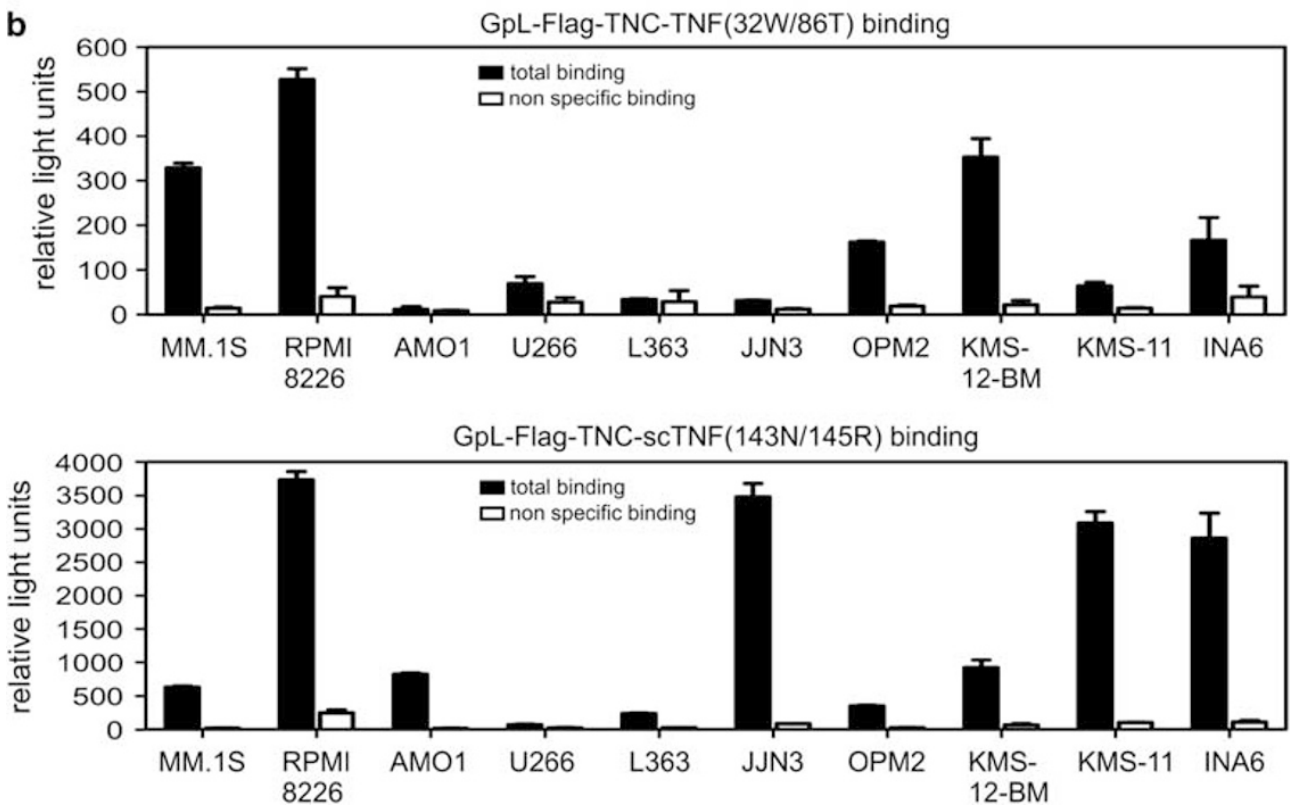

Figure 1 TNFR1 and TNFR2 expression in multiple myeloma cell lines. (a) Cell surface expression of TNFR1 and TNFR2 of the indicated cell lines was analyzed by flow cytometry using phycoerythrin-conjugated antibodies. (b) Cells $\left(3 \times 10^{6}\right)$ of the various cell lines were preincubated in triplicates with $10 \mu \mathrm{g} / \mathrm{ml}$ of the TNFR1-specific mAb $\mathrm{H} 398$ or a mixture of $3 \mu \mathrm{g} / \mathrm{ml}$ Flag-TNC-scTNF(143N/145R) and $3 \mu \mathrm{g} / \mathrm{ml}$ Flag-TNF for $1 \mathrm{~h}$ on ice or left untreated. Cells were then incubated with Gaussia princeps luciferase fusion proteins of TNFR1- (GpL-Flag-TNC-TNF(32W/86T), $200 \mathrm{ng} / \mathrm{ml}$ ) and TNFR2-specific (GpL-Flag-TNC-scTNF(143N/145R), $100 \mathrm{ng} / \mathrm{ml})$ TNF mutants for an additional hour. After removal of unbound ligand, cell-associated luciferase activity was determined using a commercially available luciferase assay. The difference in cell-associated luciferase activity between samples only treated with the Gaussia princeps luciferase fusion proteins and the corresponding samples preincubated with H398 or the Flag-TNC$\operatorname{scTNF}(143 N / 145 R) / F l a g-T N F$ mixture, gives the specific binding. Please note the different scales of the $y$-axes for TNFR1 and TNFR2 binding

Increased cell surface expression of CD95 was also mirrored by increased amounts of CD95, FADD and caspase-8 present in FC-CD95L immunoprecipitates (Figure 4c). Of note, recruitment of the antiapoptotic protein FLIP was also increased, but this effect appeared to be overcompensated by the concomitantly enhanced recruitment of FADD and caspase-8 (Figure 4c). Soluble TNF predominantly acts via TNFR1. ${ }^{15,16}$ The effects of priming with soluble TNF on 

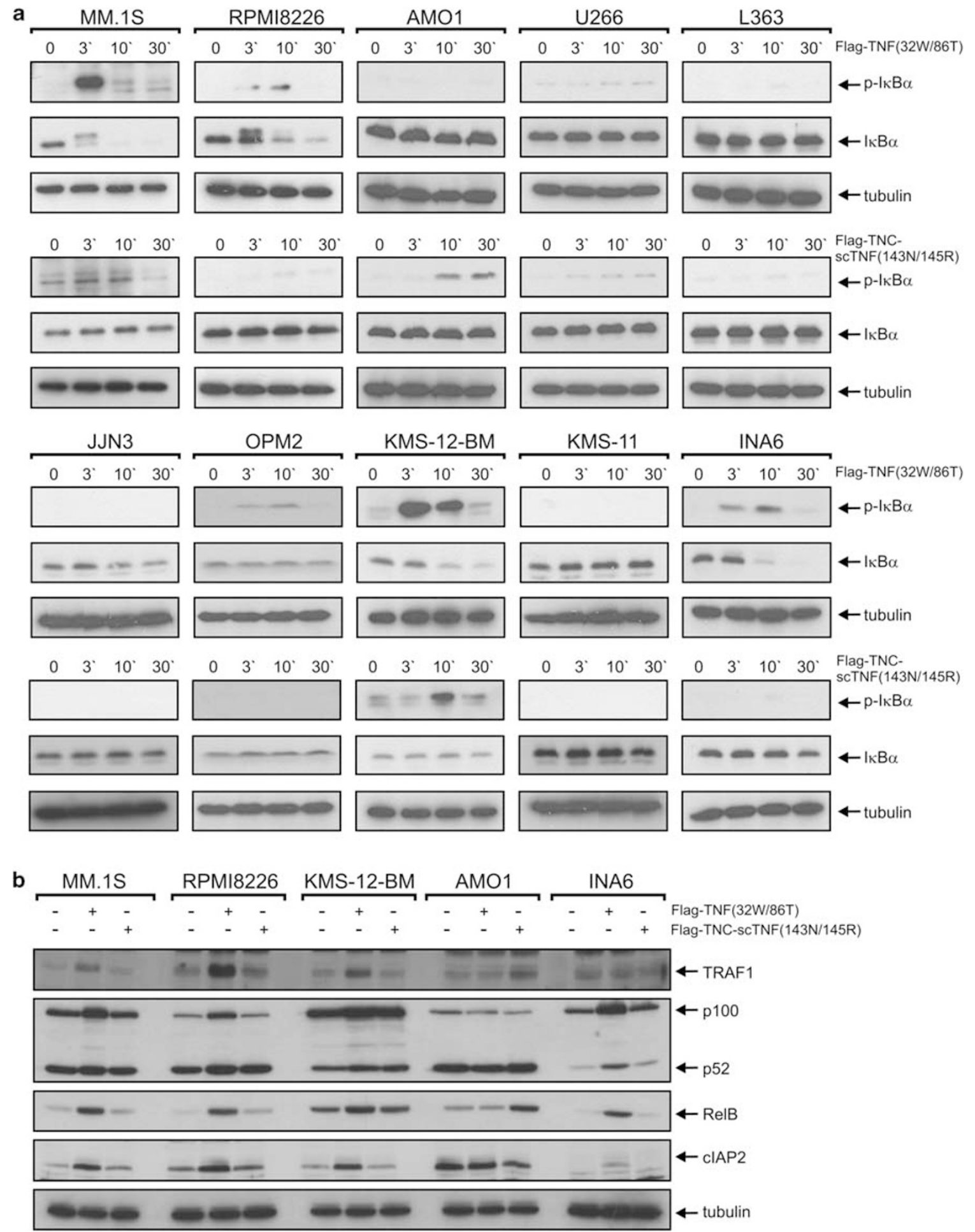

Figure 2 TNFR1 and TNFR2 activate the classical NF $\kappa$ B pathway in myeloma cells. (a) The indicated cell lines were stimulated with $200 \mathrm{ng} / \mathrm{ml}$ Flag-TNF(32W/86T) or $200 \mathrm{ng} / \mathrm{ml}$ of Flag-TNC-scTNF(143N/145R) for $0,3,10$ and $30 \mathrm{~min}$. Activation of the classical NF $\kappa$ B pathway was monitored by preparing whole-cell lysates that were subjected to western blot analysis using antibodies recognizing phospho-l $\mathrm{I}_{\kappa} \alpha$ and $I \kappa \mathrm{B} \alpha$. Detection of tubulin served as a loading control. (b) Cells were stimulated with $200 \mathrm{ng} / \mathrm{ml} \mathrm{Flag-TNF}(32 \mathrm{~W} / 86 \mathrm{~T})$ and $200 \mathrm{ng} / \mathrm{ml}$ of Flag-TNC-scTNF(143N/145R) for $24 \mathrm{~h}$, and whole-cell lysates were analyzed by western blotting for the expression of the indicated proteins

CD95L- and TRAIL-induced cell death should therefore be due to activation of TNFR1. To confirm this by an independent experimental approach, we used TNFR1- and
TNFR2-specific activators for myeloma cell priming. For selective stimulation of TNFR1 we used Flag$\mathrm{TNF}(32 \mathrm{~W} / 86 \mathrm{~T})$, and for triggering of TNFR2 we used again 

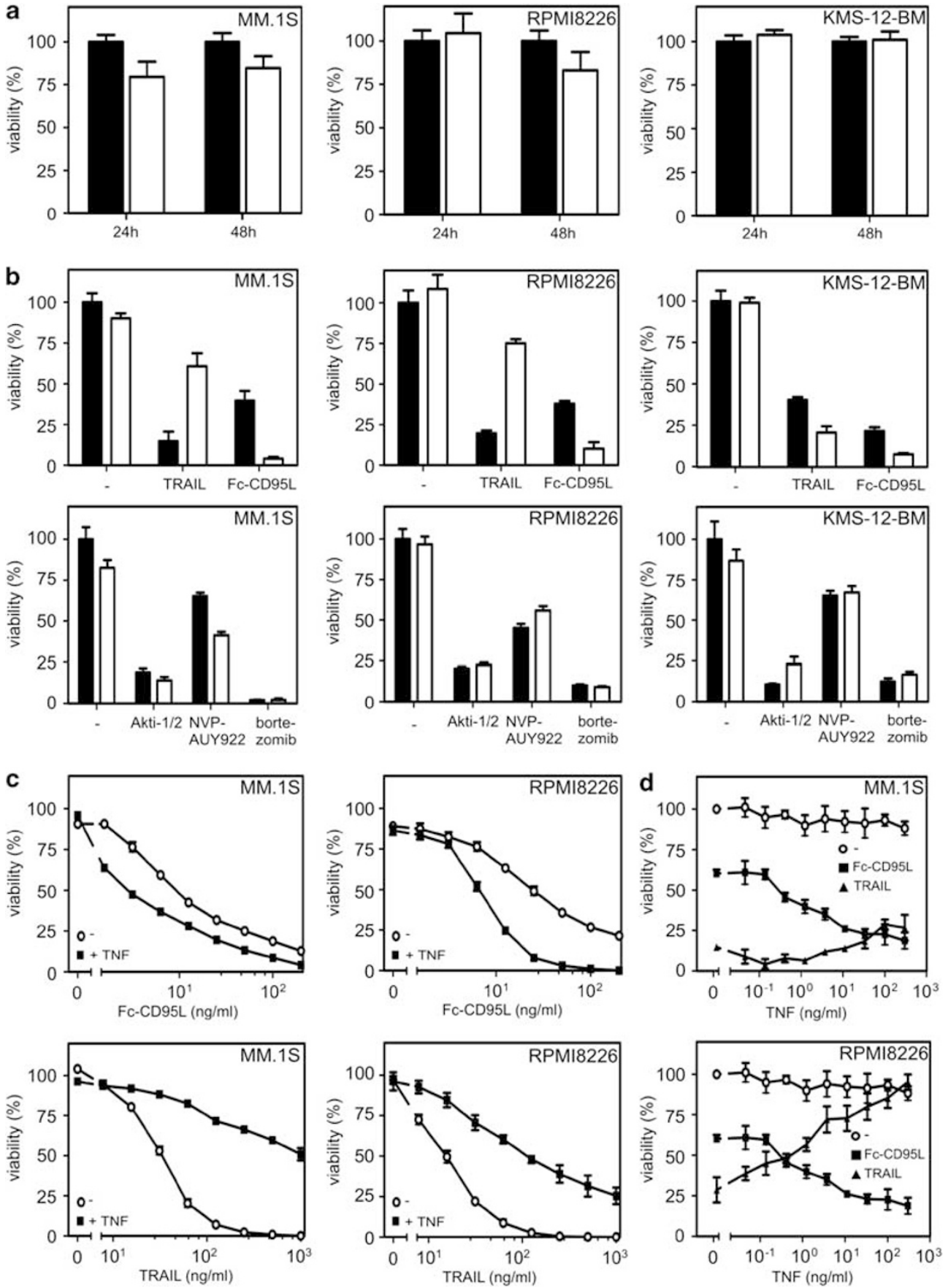

Figure 3 TNF priming has opposing effects on CD95L- and TRAIL-induced cell death in myeloma cells. (a) MM.1S, RPMI8226 and KMS-12-BM cells were challenged in three independent experiments in triplicates in 96-well plates with $50 \mathrm{ng} / \mathrm{ml}$ TNF (open bars) or remained untreated (filled bars), and viability was determined after 24 and $48 \mathrm{~h}$ using the MTT assay. (b) TNF-primed ( $50 \mathrm{ng} / \mathrm{ml}, 18 \mathrm{~h}$; open bars) and untreated cells (filled bars) were treated for $24 \mathrm{~h}$ with TRAIL (MM.1S and RPMI8226: $100 \mathrm{ng} / \mathrm{ml}$; KMS12-BM: $200 \mathrm{ng} / \mathrm{ml}$ ), Fc-CD95L (MM.1S: $2.5 \mathrm{ng} / \mathrm{ml}$; RPMl8226: $10 \mathrm{ng} / \mathrm{ml}$; KMS-12-BM: $1 \mathrm{ng} / \mathrm{ml}$ ), Akti-1/2 (MM.1S: $10 \mu \mathrm{M}$; RPMl8226 and KMS-12-BM: $50 \mu \mathrm{M}$ ), NVP-AUY922 (MM.1S: 400 nM; RPMI8226 and KMS-12-BM: 1000 nM) and bortezomib (MM.1S: 5 nM; RPMI8226 and KMS-12-BM: 20 nM). Viability was again determined by the MTT assay. (c) Cells were primed in 96-well plates (triplicates) with TNF $(50 \mathrm{ng} / \mathrm{ml}, 18 \mathrm{~h})$ and were then challenged for an additional day with the indicated concentration of TRAlL and Fc-CD95L, and finally viability was determined with the MTT assay. (d) Cells were primed in 96-well plates (triplicates) with the indicated concentrations of soluble TNF for $18 \mathrm{~h}$ and were subsequently stimulated with TRAIL ( $50 \mathrm{ng} / \mathrm{ml}$ ) and Fc-CD95L (MM. $1 \mathrm{~S}: 5 \mathrm{ng} / \mathrm{ml}$; RPMl8226: $25 \mathrm{ng} / \mathrm{ml}$ ) for an additional $24 \mathrm{~h}$ before viability was determined by MTT assay

the TNFR2-specific membrane TNF-mimicking non-americ variant Flag-TNC-scTNF(143N/145R). Priming of MM.1S and RPMI8226 cells with the TNFR1-specific variant of soluble TNF elicited the same effect on TRAIL- and CD95L- induced apoptosis and receptor expression as wild-type TNF (Figures $4 \mathrm{~b}$ and $5 \mathrm{a}, \mathrm{b}$ ). In contrast, the TNFR2-specific nonameric TNF mutant showed no effect on apoptosis induction and CD95 expression (Figures $5 \mathrm{a}$ and b). To further verify 
a

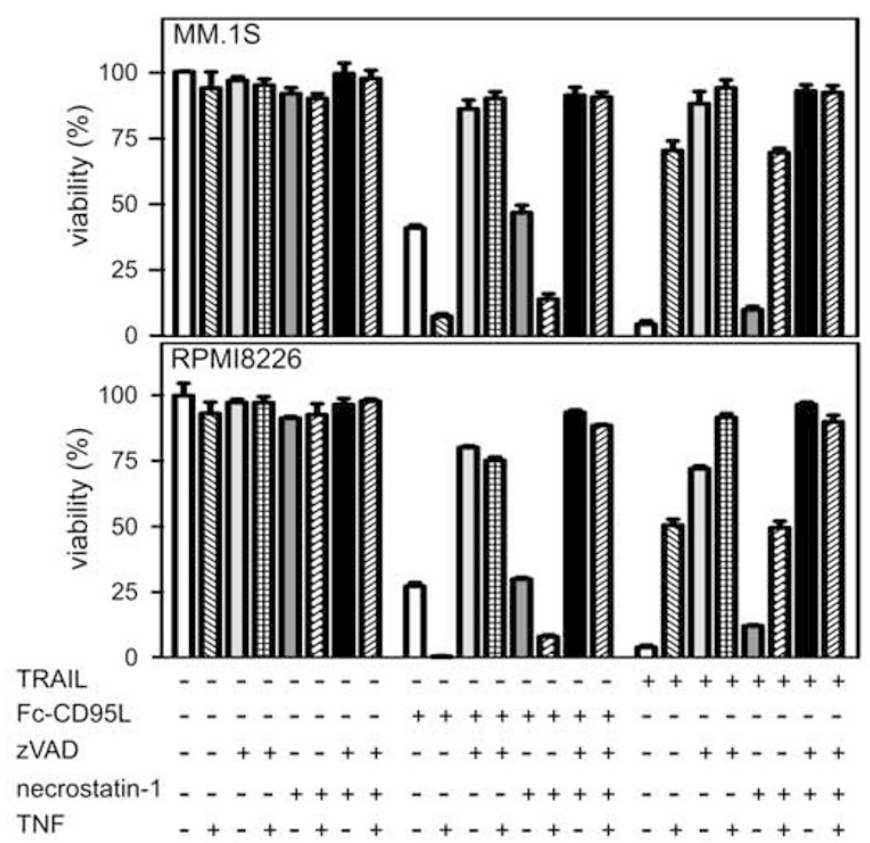

b
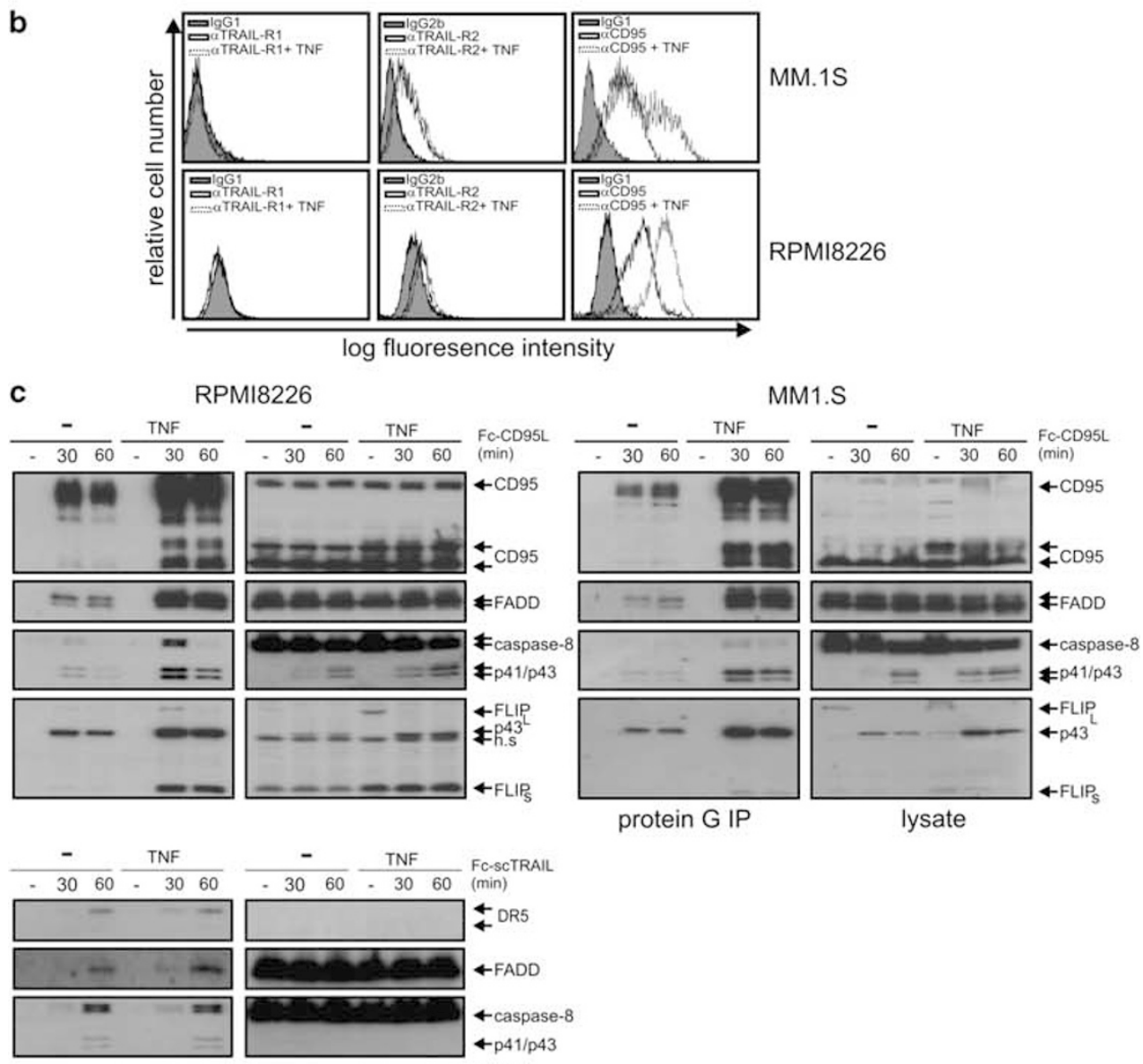

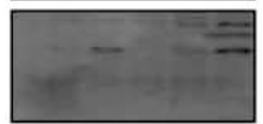

protein G IP

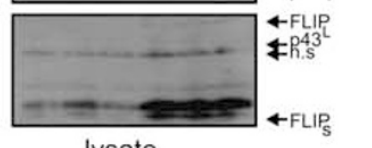

lysate 
whether TNF-induced upregulation of CD95 was due to the activation of the classical $\mathrm{NF}_{\kappa} \mathrm{B}$ pathway, we took advantage of the IKK2 inhibitor TPCA-1. The latter allows efficient inhibition of the classical $\mathrm{NF}_{\kappa} \mathrm{B}$ pathway but does not interfere with the activity of the alternative $N F \kappa B$ pathway, ${ }^{8}$ which utilizes the IKK2-related kinase IKK1. 5,6 TPCA-1 treatment alone had no effect on basal CD95 expression but completely abrogated upregulation of CD95 by TNF (Figure 6a). Moreover, RPMI8226 cells primed with TNF in the presence of TPCA-1, also failed to respond with an enhancement of CD95L-induced apoptosis (Figure 6b). TNF priming in the presence of TPCA-1 resulted in synergistic cell death induction in MM.1S cells, and thus prevented in this case analysis of the TNF-CD95L crosstalk (Figure 6c). The latter finding could be indicative for a protective effect of $\mathrm{NF}_{\kappa} \mathrm{B}$ activity with regard to $\mathrm{MM}$-associated TNF expression. In fact, IKK2 inhibition also sensitized two of the five remaining TNFR1-expressing MM cell lines (OPM2, KMS12-BM) analyzed in Figure 1 for TNF-induced cell death (Figure 6c). a

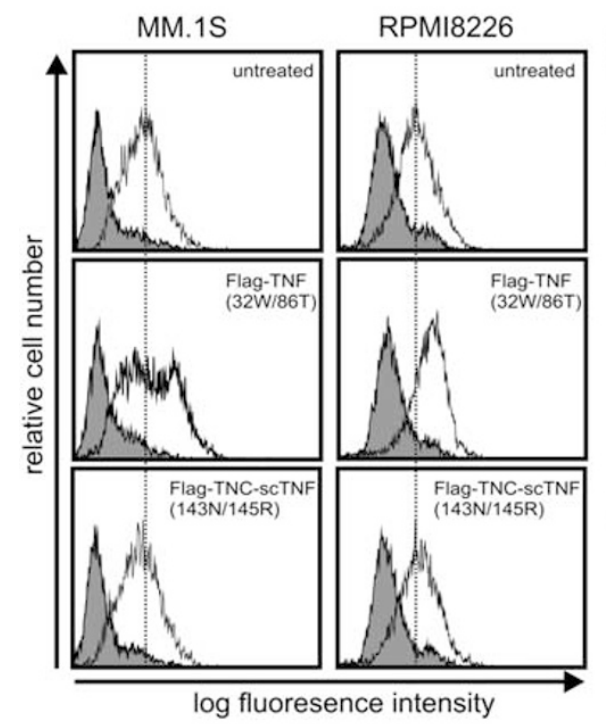

log fluoresence intensity
TNFR2 regulates TNFR1-mediated cell death-induction and TRAF2-related signaling events. The best investigated aspect of TNFR2 signaling is recruitment of TRAF2 and the TRAF2-associated proteins, clAP1 and clAP2. ${ }^{17,18}$ This results in limited availability of these proteins for other binding partners, such as the TRAF3-NIK and the TNFR1 signaling complex. ${ }^{11}$ Due to the degradationinducing effect of clAP1 and clAP2 on TRAF3-associated NIK, ${ }^{19,20}$ TNFR2 stimulation can therefore result in accumulation of $\mathrm{NIK}$, and subsequent activation of IKK1 and p100 processing thus leading to activation of the alternative $\mathrm{NF}_{\kappa} \mathrm{B}$ pathway. ${ }^{8}$ In the context of TNFR1 signaling TRAF2-clAP1/2 complexes are also of pivotal relevance for activation of the classical $\mathrm{NF}_{\kappa} \mathrm{B}$ pathway and in addition prevent RIP1-mediated caspase-8 activation. ${ }^{7,21}$ Accordingly, it has been found that TNFR2 activation antagonizes TNFR1-induced $\mathrm{NF} \kappa \mathrm{B}$ activation and enhances cell death induction. ${ }^{22}$ In view of the broad expression of TNFR2 in myeloma cells (Figure 1), we analyzed whether TNFR2 has similar signaling capabilities
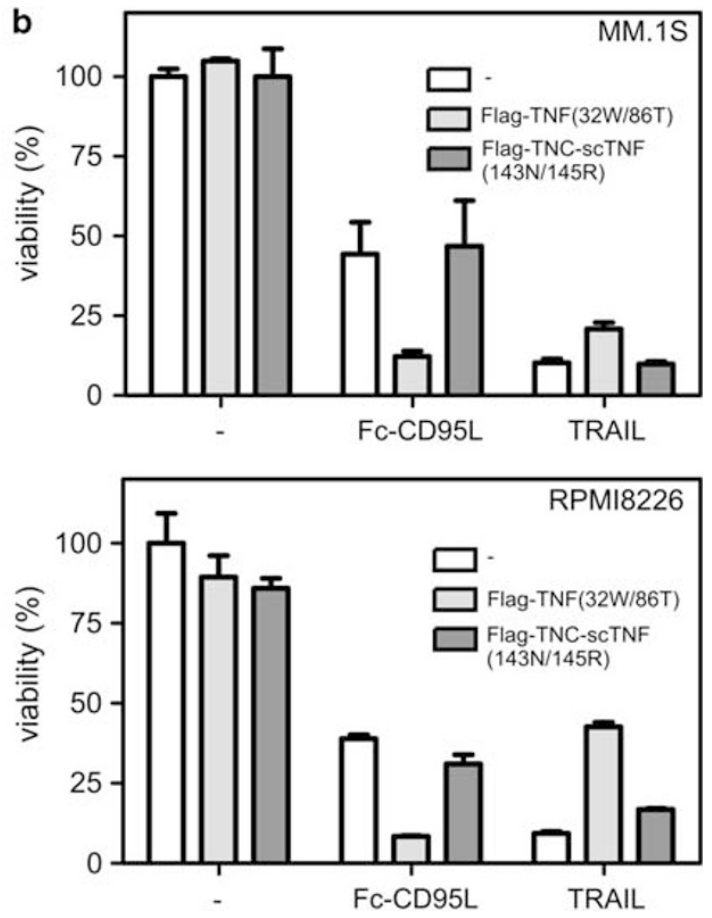

Figure 5 The differential effect of TNF on CD95L- and TRAIL-induced apoptosis in multiple myeloma cells is mediated by TNFR1. (a) MM.1S and RPMI8226 cells were primed with $200 \mathrm{ng} / \mathrm{ml}$ of the TNFR1-specific mutant Flag-TNF(32W/86T) or the TNFR2-specific TNF variant Flag-TNC-scTNF(143N/145R) or remained untreated. Cell surface expression of CD95 (unfilled curves) and IgG1 as control (filled curves) were then analyzed by FACS. (b) MM.1S and RPMI8226 cells were again primed with the TNF receptor-specific TNF variants (Flag-TNF(32W/86T): $50 \mathrm{ng} / \mathrm{ml}$; Flag-TNC-scTNF(143N/145R): $200 \mathrm{ng} / \mathrm{ml}$ ), and were stimulated the next day for $24 \mathrm{~h}$ with Fc-CD95L (MM.1S: $1 \mathrm{ng} / \mathrm{ml}$; RPMI8226: $5 \mathrm{ng} / \mathrm{ml})$ and TRAIL $(100 \mathrm{ng} / \mathrm{ml})$. Viability was determined by MTT assay

Figure 4 TNF upregulates cell surface expression of CD95. (a) MM.1S and RPMI8226 cells were primed with TNF ( $50 \mathrm{ng} / \mathrm{ml})$ for $18 \mathrm{~h}$ or remained untreated. Cells were then treated in triplicates with the indicated mixtures of TRAIL (200 ng/ml), Fc-CD95L (MM.1S: $30 \mathrm{ng} / \mathrm{ml}$; RPMI8226: $60 \mathrm{ng} / \mathrm{ml}), \mathrm{ZVAD}(40 \mu \mathrm{M})$ and necrostatin-1 $(90 \mu \mathrm{M})$, and viability was determined after $24 \mathrm{~h}$ by MTT staining. (b) Cell surface expression of CD95, TRAILR1 and TRAILR2 of untreated and TNF-primed ( $200 \mathrm{ng} / \mathrm{ml}, 18 \mathrm{~h}$ ) myeloma cells were analyzed by FACS. (c) Untreated and TNF-primed $(50 \mathrm{ng} / \mathrm{ml}, 18 \mathrm{~h}) \mathrm{MM} .1 \mathrm{~S}$ and RPMI8226 cells were stimulated for the indicated times with Fc-CD95L $(1 \mu \mathrm{g} / \mathrm{ml}$; upper panel). Untreated and TNF-primed $(50 \mathrm{ng} / \mathrm{ml}, 18 \mathrm{~h})$ RPMl 8226 cells were also stimulated with Fc-scTRAlL $(200 \mathrm{ng} / \mathrm{ml}$; lower panel). CD95L- and Fc-scTRAlL-associated proteins were then immunoprecipitated using protein $\mathrm{G}$ agarose, and immunoprecipitates and cell lysates were finally analyzed for the presence of the indicated proteins by western blotting. Cell lysates supplemented with $10 \mathrm{ng}$ of Fc-CD95L or Fc-ScTRAIL were immunoprecipitated as negative controls 
a

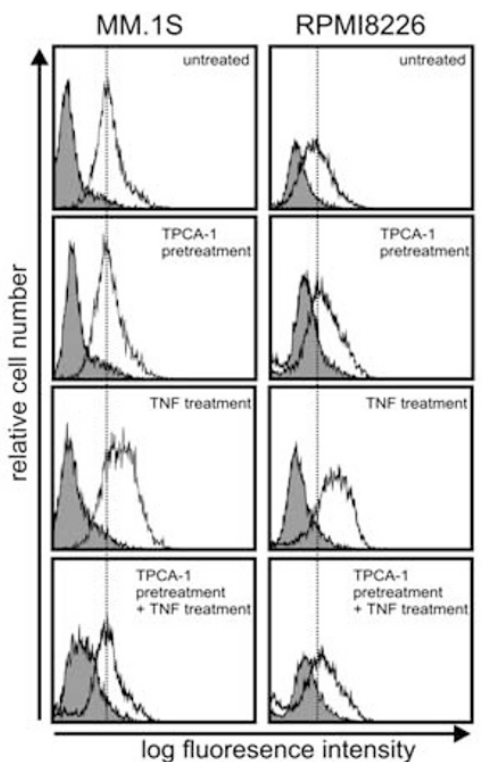

b

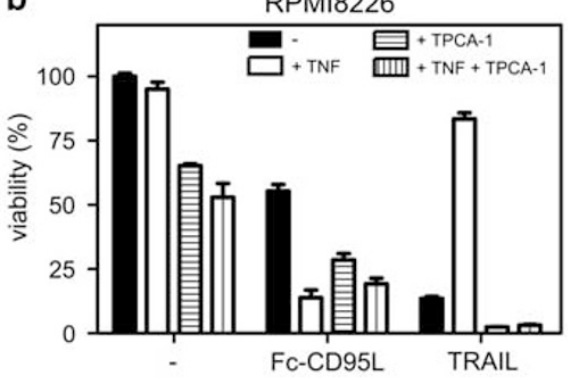

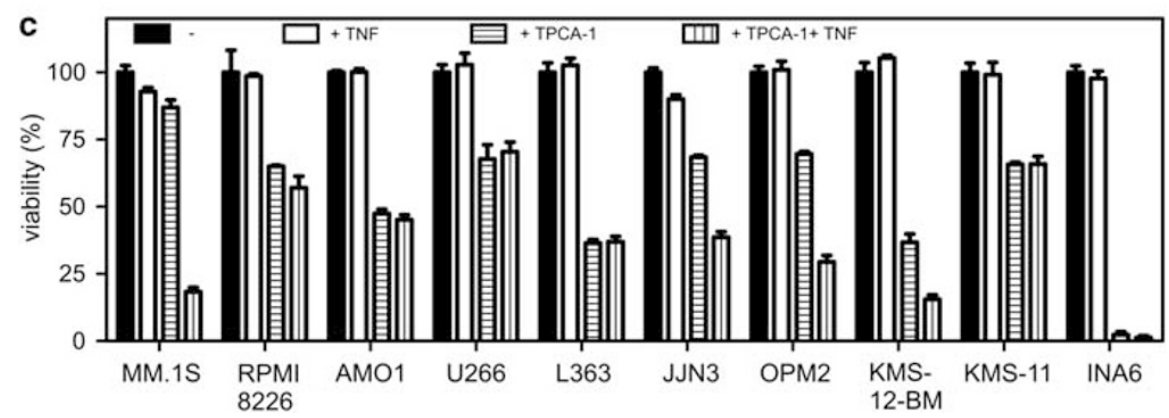

Figure 6 The IKK2 inhibitor TPCA-1 inhibits TNF-induced upregulation of CD95 expression and modulation of TRAIL- and CD95L-induced apoptosis. (a) MM.1S and RPMI8226 cells were primed with $200 \mathrm{ng} / \mathrm{ml}$ TNF for $18 \mathrm{~h}$ in the presence and absence of $10 \mu \mathrm{M} \mathrm{TPCA}-1$. Cell surface expression of CD95 (unfilled curves) and lgG1 as control (filled curves) were analyzed by FACS. (b) RPMI8226 cells were treated as indicated with TNF ( $50 \mathrm{ng} / \mathrm{ml}$ ) and TPCA-1 (10 $\mu$ M) for $18 \mathrm{~h}$ and were challenged the next day for $24 \mathrm{~h}$ with TRAIL $(200 \mathrm{ng} / \mathrm{ml})$ and Fc-CD95L $(10 \mathrm{ng} / \mathrm{ml})$. Cellular viability was determined with the MTT assay. (c) Cells were stimulated with the indicated mixtures of TNF $(50 \mathrm{ng} / \mathrm{ml})$ and TPCA-1 $(10 \mu \mathrm{M})$ and were analyzed for cellular viability after $42 \mathrm{~h}$ by MTT assay

in myeloma cell lines. Analysis of total cell lysates revealed that TNFR2 stimulation triggered robust (JJN3, AMO1 and KMS11) to moderate (RPMI8226, KMS-12-BM, INA6 and OPM2) TRAF2 degradation in 7 of the 10 investigated cell lines (Figure 7a). In five cases this was accompanied by accumulation of NIK (Figure 7a). Surprisingly, however, none of the cell lines responded with appreciable 100 processing. In accordance with the antiapoptotic function of TRAF2 in TNFR1 signaling, we observed enhanced TNFR1-induced cell death in JJN3 but not in the other cells (Figure $7 \mathrm{~b}$ and data not shown). Thus, although TNFR2 stimulation significantly affected TRAF2 and NIK expression in most MM cell lines, this resulted only in one case in a corresponding downstream $\mathrm{p} 100$ processing effect.

\section{Discussion}

Transcription factors of the $\mathrm{NF} \kappa \mathrm{B}$ family regulate a variety of genes required for growth, survival and migration of cells. It is therefore not surprising that deregulated activation of the $\mathrm{NF} \kappa \mathrm{B}$ system has been implicated in cancer development and metastasis. In multiple myeloma, there is evidence that $\mathrm{NF}_{\kappa} \mathrm{B}$ activity promotes growth, immortalization and survival of tumor cells as well as angiogenesis. ${ }^{23}$ For example, NF $k \mathrm{~B}$ inhibitory drugs, such as the proteasome inhibitor bortezomib or IKK2 inhibitors, reduce proliferation and enhance apoptosis in myeloma cells. ${ }^{3,24-27}$ Moreover, two recent studies demonstrated that more than $80 \%$ of myeloma biopsies have a gene expression signature characteristic for $\mathrm{NF} \kappa \mathrm{B}$ activity; and furthermore identified in a considerable fraction of $\mathrm{MM}$ cell lines and patient samples (close to $20 \%$ ), genetic lesions that could lead to cell autonomous activation of $\mathrm{NF} \kappa \mathrm{B}$ signaling. ${ }^{3,4}$ TNF is a strong activator of the classical $N F_{\kappa} B$ pathway and is itself regulated by this pathway. ${ }^{9}$ Although increased TNF levels have consistently been observed in multiple myelo$\mathrm{ma}^{28-32}$ there are conflicting data on an association of high producer alleles of the $T N F$ and $L T \alpha$ genes with the risk for multiple myeloma ${ }^{31,33-38}$ Notably, a pilot study in which 10 patients with refractory multiple myeloma received medical treatment with a soluble TNFR2 fusion protein (Enbrel/ Etanercept) come out with the unexpected result that TNF plasma levels were significantly increased. Moreover, 4 of the 
a

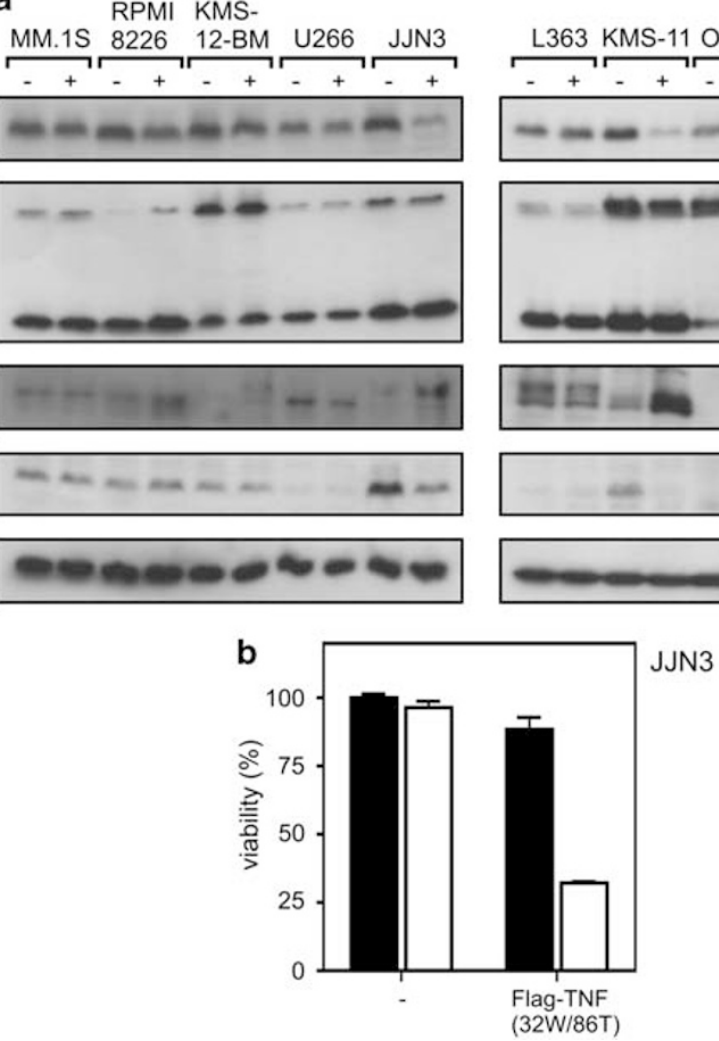

Figure 7 TNFR2 triggers TRAF2 degradation and NIK accumulation in myeloma cell lines. (a) The indicated myeloma cell lines were stimulated with $200 \mathrm{ng} / \mathrm{ml}$ of the TNFR2-specific TNF variant Flag-TNC-scTNF(143N/145R) for $18 \mathrm{~h}$. Whole-cell lysates were subjected to western blot analysis to detect the indicated proteins. (b) JJN3 cells were primed overnight with $200 \mathrm{ng} / \mathrm{ml}$ Flag-TNC-scTNF(143N/145R) (open bars) or remained untreated (filled bars) and challenged the next day with $200 \mathrm{ng} / \mathrm{ml}$ Flag$\mathrm{TNF}(32 \mathrm{~W} / 86 \mathrm{~T})$ for $24 \mathrm{~h}$. Cell viability was determined by MTT assay

10 patients, three with stable and one with progressive disease at therapy start, showed progressive disease during therapy. ${ }^{39}$ The basis of this counterintuitive increase in TNF in the presence of Enbrel is unclear but could be related, among other things, to reverse signaling of membrane TNF or differential inhibition of soluble and membrane TNF and thus differential inhibition of TNFR1 and TNFR2 that can elicit opposing effects on $\mathrm{NF}_{\kappa} \mathrm{B}$ signaling. ${ }^{11,40}$ In any case this pilot study provides initial evidence that the TNF/TNF receptor system is not only active in multiple myeloma but also of significance for the course of the disease.

In view of the pivotal role of the classical NF $\kappa$ B pathway for cell survival, we asked in this study whether TNF modulates the sensitivity of MM cell lines for apoptosis. First, we analyzed various myeloma cell lines with respect to the cell surface expression of the two TNF receptors TNFR1 and TNFR2. Although TNFR2 expression was found on 9 of 10 cell lines, TNFR1 expression was rather restricted (Figure 1). TNFR1 is the major receptor involved in TNF-induced activation of the classical $\mathrm{NF}_{\kappa} \mathrm{B}$ pathway. ${ }^{8,9}$ Therefore, we initially focused our analysis on MM.1S and RPMI8226 cells that showed strong TNFR1-mediated NF $\kappa$ B activation in terms of phosphorylation and degradation of $\mathrm{I} \kappa \mathrm{B} \alpha$ and upregulation of $\mathrm{NF} \kappa \mathrm{B}$-regulated factors (Figures $2 \mathrm{a}$ and $\mathrm{b}$ ). TNFR1, CD95 and the two TRAIL death receptors, TRAILR1 and TRAILR2, all belonging to the death receptor subgroup of the TNF receptor family, signal apoptosis by FADD and caspase-8. ${ }^{9,13}$ Notably, however, while FC-CD95L and TRAIL potently induced apoptosis in both cell lines within $18 \mathrm{~h}$, treatment with soluble TNF, thus TNFR1 activation, elicited no or only a very minor growth inhibitory effect (Figure 3 ). This different sensitivity is typically also observable in other cell types and might mainly reflect the fact that TNFR1-associated caspase-8 activation, in contrast to CD95-, TRAILR1- and TRAILR2-associated activation of this protein, is not only inhibited by FLIP proteins but also by TRAF2-cIAP1/2containing complexes. ${ }^{22}$ Consequently, we and others found that cytoplasmic deviation of these complexes by recruitment to TRAF2-clAP1/2-interacting receptors, such as TNFR2, results in enhanced TNFR1-induced cell death (for review, see Naude et al. ${ }^{22}$ ). In accordance with the idea that such TRAF2-containing complexes are also operative in myeloma cells, we indeed noticed enhanced TNFR1-induced cell death in TNFR2-primed JJN3 cells (Figure 7b).

Although activation of the classical $\mathrm{NF}_{\kappa} \mathrm{B}$ pathway has frequently been implicated in development of resistance against chemotherapeutic drugs, ${ }^{41}$ we observed no inhibitory effect of TNF priming on cell death induction by different types of anti-myeloma drugs despite upregulation of anti-apoptotic proteins, such as clAP2 and FLIP $P_{\mathrm{LS}}$ (Figures $2 \mathrm{~b}$ and $4 \mathrm{c}$ ). Surprisingly, however, TNF priming elicited opposing effects on TRAIL- and CD95L-induced cell death (Figures 3b-d), 
although the corresponding death receptors trigger apoptosis by the same receptor-associated mechanisms. ${ }^{13}$ The latter suggested that TNF priming acts, at least partly, upstream of caspase-8 on receptor-proximal steps in TRAIL- and CD95Linduced apoptosis. Indeed, CD95 and both TRAIL death receptors as well as the FLIP proteins are regulated by the classical $\mathrm{NF}_{\kappa} \mathrm{B}$ pathway in a cell-type-specific manner. ${ }^{42-47}$ FACS analysis, western blotting and immunoprecipitation experiments revealed that TNFR1 activation enhances cell surface expression of CD95 but not of the TRAIL death receptors in myeloma cells (Figures $4 b$ and $c$ ). Experiments using the IKK2 inhibitor TPCA-1 further indicated that the TNF-induced upregulation of CD95 expression occurred via the classical $\mathrm{NF}_{\kappa} \mathrm{B}$ pathway (Figure $6 \mathrm{a}$ ). Moreover, in RPMI8226 cells TPCA- 1 not only prevented TNFR1-mediated upregulation of CD95 (Figure 6a) but also diminished the enhancing effect of TNF on CD95L-induced apoptosis (Figure 6b). TNF-mediated sensitization for apoptosis induction by CD95 upregulation has previously been observed also in the $\mathrm{OH} 2$ myeloma cell line, ${ }^{48}$ and $\mathrm{NF}_{\kappa} \mathrm{B}$-mediated CD95 upregulation has recently been found to exert proapoptotic effects in an animal model of cMyc-induced lymphomagenesis. ${ }^{49}$

Although the IKK2-mediated upregulation of CD95 explains why TNF priming sensitizes for CD95L, but not for TRAILinduced apoptosis, it does not provide an answer for the mechanism(s) underlying the protective effect of TNF priming against TRAIL. The most relevant protective factors regulated by $\mathrm{NF}_{\kappa} \mathrm{B}$ in the context of death receptor signaling are certainly the FLIP proteins. The different isoforms of FLIP corecruit with caspase- 8 to the TRAIL death receptors and CD95 where they interfere with caspase-8 maturation. ${ }^{9}$ Analysis of cell lysates and immunoprecipitates of CD95 and TRAIL receptors of TNF-primed MM cells indeed revealed upregulation of FLIP (Figure 4c). Moreover, in accordance with an increased inhibitory effect of FLIP proteins on TRAIL-induced apoptosis in TNF-primed cells, there was reduced processing of the long isoform of FLIP in the TRAIL-associated receptor signaling complex as well as increased recruitment of this protective factor (Figure 4c). In sum, these data suggest the following model (Figure 8): activation of the classical $N F \kappa B$ pathway via TNFR1 results in the upregulation of CD95 and FLIP proteins. With respect to TRAIL signaling only the latter is of relevance and has a protective effect. In case of CD95 signaling, however, there are two opposing effects, moderate upregulation of FLIP and strong upregulation of CD95, the net effect of which is enhanced CD95-mediated apoptosis.

In this study we identified multiple mechanisms by which TNF and its receptors regulate the sensitivity of myeloma cell lines for extrinsic apoptosis. In view of the quite variable expression of the two TNF receptors in the different myeloma cell lines and the known heterogeneity of genetic alterations in multiple myeloma, it should not be surprising that these mechanisms are not equally effective in all cell lines investigated but rather occur in each case only in a subset of the cell lines. A major difference between primary myeloma samples and myeloma cell lines is the much higher proliferative capacity of the latter. It is thus desirable to recapitulate findings obtained from experiments with cell lines

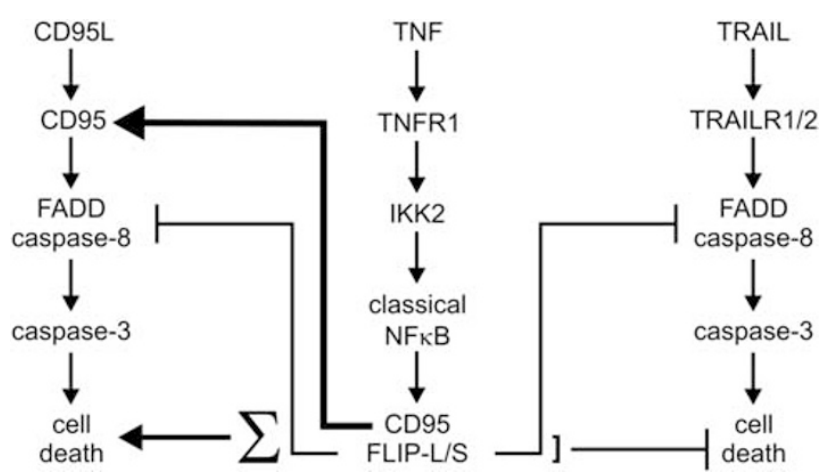

Figure 8 Model of the differential regulation of CD95L- and TRAIL-induced apoptosis by TNFR1. TNFR1-induced activation of the classical NF $\kappa$ B pathway results in concomitant upregulation of FLIP $\mathrm{P}_{\mathrm{LS}}$ and CD95. Although upregulation of FLIP $_{\mathrm{L} / \mathrm{S}}$ antagonizes TRAIL-induced apoptosis, this effect is overcompensated in context of CD95L-induced signaling by the strong increase in CD95 expression

with primary myeloma cells. Biopsies of patients suffering from multiple myeloma typically contain very limited numbers of cells $\left(10^{5}-10^{6}\right)$ and their clinical frequency is rather moderate. Analysis of primary myeloma samples is therefore more practicable for the investigation of processes occurring in a large fraction of primary samples and requiring only a low number of experimental groups. However, this approach is poorly feasible for investigations of scenarios like those studied in this study that possibly occur only in a fraction of samples and requires the parallel analysis of several groups (e.g. plus/minus TNF, plus/minus CD95 stimulation, plus/ minus IKK2 inhibition) by two or more parameters (e.g. cell surface receptor expression and apoptosis assay). Thus, a future challenge will be to evaluate the relevance of TNF and its receptors for the development and treatment of multiple myleoma in animal models of this disease.

\section{Materials and Methods}

Cell lines, reagents and antibodies. HEK293, MM.1S, RPMI8226, AM01, U266, L363, JJN3, OPM2, KMS-12-BM, KMS-11 and INA6 cells were maintained in RPMl1640 medium (PAA, Pasching, Germany), containing 10\% heatinactivated fetal bovine serum (PAA). For INA6 cells the culture medium was supplemented with recombinant human IL6 $(10 \mathrm{ng} / \mathrm{ml}$, ImmunoTools, Friesoythe, Germany). Mutations conferring specificity for TNFR1 and TNFR2 to soluble TNF have been described elsewhere by Loetscher et al. ${ }^{10}$ The various Flag-tagged variants of soluble TNF or CD95L used in this study were produced in HEK293 cells and purified by affinity chromatography on anti-Flag mAb M2-agarose. The pancaspase inhibitor, ZVAD, was purchased from Bachem (Weil am Rhein, Germany). Necrostatin-1, anti-FLIP (NF6, 804-428-C100) and TRAIL were from Enzo Life Sciences (Lörrach, Germany). TRAF2-specific antibody (H-249 and sc-7187), anti$\mathrm{I}_{\kappa \mathrm{B}} \alpha$ (FL and sc-847), anti-CD95 (C-20 and sc-715) and anti-FADD (H-181 and sc-5559) were purchased from Santa Cruz Biotechnology (Santa Cruz, CA, USA). Anti-tubulin (DM1A and MS-581-P) was from Neomarkers (Fremont, CA, USA), anti-p100 (05-361) from Millipore (Temecula, CA, USA), anti-cIAP2 (51-9000062) was from BD (Heidelberg, Germany), and anti-NIK (4994), anti-rabbitHRP (7074) and anti-pl $\kappa \mathrm{B} \alpha(\mathrm{S} 32,2859 \mathrm{~L})$ were from Cell Signaling Technologies (Danvers, MA, USA). Anti-mouseHRP (p0260) and anti-rabbitHRP (p0448) were from Dako (Hamburg, Germany). Anti-caspase-8 was a kind gift of Prof. K. Schulze-Osthoff (University of Tübingen, Germany). The IKK2 inhibitor TPCA-1 was from Tocris Bioscience (Ellisville, MO, USA) and Akti-1/2 from Merck (Darmstadt, Germany). Protein G-agarose was from Roche (Mannheim, Germany). The phycoerythrinconjugated antibodies anti-TNFR1(FAB225P), anti-TNFR2 (FAB226P), antiTRAILR1 (FAB347P), anti-TRAILR2 (FAB6311P), anti-lgG1 (IC002P), anti-IgG2a (IC003P), and IgG2b (IC0041P) and the fluorescein isothiocyanate-conjugated 
anti-CD95 (FAB142F) and anti-IgG1 (ICO02F) were from R\&D Systems (Wiesbaden-Nordenstadt, Germany).

Flow cytometry. Cells were stained with phycoerythrin- or fluorescein isothiocyanate-conjugated monoclonal antibodies specific for TNFR1, TNFR2, CD95, TRAILR1 and TRAILR2 or with corresponding isotype control antibodies for 20 min on ice, and after two washes with PBS cells were analyzed by flow cytometry using a FACS flow cytometer and the corresponding software supplied by the manufacturer (BD Calibur, BD, Heidelberg, Germany).

Binding studies with Gaussia princeps luciferase TNF fusion proteins. Cells $\left(3 \times 10^{6}\right)$ were incubated with either the TNFR1-specific mAb H398 $(10 \mu \mathrm{g} / \mathrm{ml}$ ) (a kind gift of Profs. K. Pfizenmaier and P. Scheurich, University of Stuttgart, Germany) or a mixture of $3 \mu \mathrm{g} / \mathrm{ml}$ Flag-TNC-scTNF(143N/145R) and $3 \mu \mathrm{g} / \mathrm{ml}$ Flag-TNF for $1 \mathrm{~h}$ on ice or left untreated. Cells were then incubated for another hour on ice with TNFR1- $(200 \mathrm{ng} / \mathrm{ml})$ or TNFR2- $(100 \mathrm{ng} / \mathrm{ml})$ specific Gaussia princeps luciferase fusion proteins of Flag-TNC-TNF(32W/86T) and Flag-TNC-scTNF(143N/ 145R). To remove unbound ligand, cells were washed three times with ice-cold PBS and were suspended in $50 \mu \mathrm{l}$ culture medium with $0.5 \%$ FBS in a black 96 -well plate. Luciferase activity was determined by using a Luciferase Assay Kit (New England Biolabs GmbH, Frankfurt a. M., Germany) and measured in a Luminometer (Lucy 2, Anthos Labtec Instruments, Wals/Salzburg, Austria). Specific binding is the difference of total binding (i.e. luciferase activity of cells treated with the luciferase fusion proteins alone) and non-specific binding (i.e. the activity of samples which were pre-incubated with $\mathrm{H} 398$ or a mixture of Flag-TNC-scTNF(143N/145R) and Flag-TNF as blocking reagents).

Death-inducing signaling complex analysis. Cells $\left(70 \times 10^{6}\right.$ in $\left.5 \mathrm{ml}\right)$ were stimulated with Fc-CD95L $(1 \mu \mathrm{g} / \mathrm{ml})$ or Fc-scTRAIL $(200 \mathrm{ng} / \mathrm{ml})$ for the indicated times at $37^{\circ} \mathrm{C}$ or remained untreated. After two washes with ice-cold phosphate-buffered saline, cells were lysed by incubation ( $20 \mathrm{~min}$ on ice) in $1.5 \mathrm{ml}$ lysis buffer $(30 \mathrm{mM}$ Tris- $\mathrm{HCl}, \mathrm{pH} 7.5,1 \%$ Triton X-100, 10\% glycerol and $120 \mathrm{mM}$ $\mathrm{NaCl}$ ) supplemented with complete protease inhibitor cocktail (Roche). Lysates were cleared by centrifugation $(30 \mathrm{~min}, 14.000 \times \mathrm{g})$, and Fc-CD95L/Fc-scTRAILassociated proteins were precipitated with protein $\mathrm{G}$ agarose beads (Roche; $20 \mu \mathrm{l}$ of a $50 \%$ slurry, overnight at $4^{\circ} \mathrm{C}$ ). As a control, lysates of unstimulated cells were supplemented with $10 \mathrm{ng}$ of the corresponding ligand and subjected to immunoprecipitation with protein $\mathrm{G}$ beads. Immuncomplexes were washed five times with ice-cold lysis buffer, and bound proteins were eluted by incubation at $70^{\circ} \mathrm{C}$ for $10 \mathrm{~min}$ in $4 \times$ Laemmli buffer and analyzed by western blotting.

Western blotting. For western blot analysis of whole cell lysates, cells were lysed in $4 \times$ Laemmli sample buffer which was supplemented with complete protease inhibitor cocktail (Roche) and phosphatase inhibitor cocktail II (SigmaAldrich, Munich, Germany). Upon sonification, samples were heated $\left(5 \mathrm{~min}, 96^{\circ} \mathrm{C}\right)$ and subjected to protein separation by SDS-PAGE. Proteins were transferred to nitrocellulose membranes by semi-dry blotting and remaining binding sites were blocked by incubation with PBS or TBS containing $0.05 \%$ Tween 20 and $5 \%$ dry milk. To detect the proteins of interest, membranes were incubated over night with corresponding primary antibodies. To finally visualize bound primary antibodies, membranes were incubated with horseradish peroxidase-conjugated secondary antibodies and the obtained antibody-containing complexes were detected with the ECL Western blotting detection system (Pierce, Thermo Fischer Scientific, Bonn, Germany).

Determination of cellular viability. The various multiple myeloma cell lines were plated into a 96-well plate and were challenged with the various stimuli as indicated in the corresponding figure legends. Metabolically active cells were finally quantified using a standard MTT protocol. Viability was calculated as percentage of the viability of untreated cells ( $100 \%$ viability). Background staining of completely killed cells ( $0 \%$ viability) was determined using a group consisting of cells that had been exposed to a deadly mixture containing CHX, TRAIL and Fc-CD95L.

\section{Conflict of Interest}

The authors declare no conflict of interest.
Acknowledgements. This work was supported by Deutsche Forschungsgemeinschaft (DFG Wa 1025/18-1; DFG Wa 1025/21-1, KFO 216 TP8).

1. Bommert K, Bargou RC, Stühmer T. Signalling and survival pathways in multiple myeloma. Eur J Cancer 2006; 42: 1574-1580.

2. Hideshima T, Bergsagel PL, Kuehl WM, Anderson KC. Advances in biology of multiple myeloma: clinical applications. Blood 2004; 104: 607-618.

3. Annunziata CM, Davis RE, Demchenko Y, Bellamy W, Gabrea A, Zhan F et al. Frequent engagement of the classical and alternative NF-kappaB pathways by diverse genetic abnormalities in multiple myeloma. Cancer Cell 2007; 12: 115-130.

4. Keats JJ, Fonseca R, Chesi M, Schop R, Baker A, Chng WJ et al. Promiscuous mutations activate the noncanonical NF-kappaB pathway in multiple myeloma. Cancer Cell 2007; 12: 131-144.

5. Hayden MS, Ghosh S. Shared principles in NF-kappaB signaling. Cell2008; 132: 344-362.

6. Scheidereit C. IkappaB kinase complexes: gateways to NF-kappaB activation and transcription. Oncogene 2006; 25: 6685-6705.

7. Wajant $\mathrm{H}$, Scheurich $\mathrm{P}$. TNFR1-induced activation of the classical NF-kappaB pathway. FEBS J 2011; 278: 862-876.

8. Rauert H, Wicovsky A, Muller N, Siegmund D, Spindler V, Waschke J et al. Membrane tumor necrosis factor (TNF) induces p100 processing via TNF receptor-2 (TNFR2). J Biol Chem 2010; 285: 7394-7404

9. Wajant $\mathrm{H}$. Death receptors. Essays Biochem 2003; 39: 53-71.

10. Loetscher $H$, Stueber D, Banner D, Mackay F, Lesslauer W. Human tumor necrosis factor alpha (TNF alpha) mutants with exclusive specificity for the $55-\mathrm{kDa}$ or $75-\mathrm{kDa}$ TNF receptors. J Biol Chem 1993; 268: 26350-26357.

11. Wicovsky A, Henkler F, Salzmann S, Scheurich P, Kneitz C, Wajant H. Tumor necrosis factor receptor-associated factor-1 enhances proinflammatory TNF receptor-2 signaling and modifies TNFR1-TNFR2 cooperation. Oncogene 2009; 28: 1769-1781.

12. Luo JL, Kamata H, Karin M. The anti-death machinery in IKK/NF-kappaB signaling. J Clin Immunol 2005; 25: 541-550

13. Wajant $\mathrm{H}$. CD95L/FasL and TRAIL in tumour surveillance and cancer therapy. Cancer Treat Res 2006; 130: 141-165.

14. Vandenabeele $P$, Galluzzi $L$, Vanden Berghe $T$, Kroemer G. Molecular mechanisms of necroptosis: an ordered cellular explosion. Nat Rev Mol Cell Biol 2010; 11: 700-714.

15. Grell M, Douni E, Wajant $H$, Lohden M, Clauss M, Maxeiner B et al. The transmembrane form of tumor necrosis factor is the prime activating ligand of the $80 \mathrm{kDa}$ tumor necrosis factor receptor. Cell 1995; 83: 793-802.

16. Grell M, Wajant H, Zimmermann G, Scheurich P. The type 1 receptor (CD120a) is the high-affinity receptor for soluble tumor necrosis factor. Proc Natl Acad Sci USA 1998; 95: 570-575

17. Rothe M, Pan MG, Henzel WJ, Ayres TM, Goeddel DV. The TNFR2-TRAF signaling complex contains two novel proteins related to baculoviral inhibitor of apoptosis proteins. Cell 1995; 83: 1243-1252.

18. Rothe M, Wong SC, Henzel WJ, Goeddel DV. A novel family of putative signal transducers associated with the cytoplasmic domain of the $75 \mathrm{kDa}$ tumor necrosis factor receptor. Cell 1994; 78: 681-692.

19. Vallabhapurapu S, Matsuzawa A, Zhang W, Tseng PH, Keats JJ, Wang $\mathrm{H}$ et al. Nonredundant and complementary functions of TRAF2 and TRAF3 in a ubiquitination cascade that activates NIK-dependent alternative NF-kappaB signaling. Nat Immuno 2008; 9: 1364-1370.

20. Zarnegar BJ, Wang Y, Mahoney DJ, Dempsey PW, Cheung HH, He J et al. Noncanonical NF-kappaB activation requires coordinated assembly of a regulatory complex of the adaptors cIAP1, cIAP2, TRAF2 and TRAF3 and the kinase NIK. Nat Immunol 2008; 9 : 1371-1378.

21. O'Donnell MA, Ting AT. RIP1 comes back to life as a cell death regulator in TNFR1 signaling. FEBS J 2011; 278: 877-887

22. Naude PJ, den Boer JA, Luiten PG, Eisel UL. Tumor necrosis factor receptor cross-talk. FEBS J 2011; 278: 888-898.

23. Li ZW, Chen H, Campbell RA, Bonavida B, Berenson JR. NF-kappaB in the pathogenesis and treatment of multiple myeloma. Curr Opin Hematol 2008; 15: 391-399.

24. Jourdan M, Moreaux J, Vos JD, Hose D, Mahtouk K, Abouladze M et al. Targeting NF-kappaB pathway with an IKK2 inhibitor induces inhibition of multiple myeloma cell growth. Br J Haematol 2007; 138: 160-168.

25. Mitsiades N, Mitsiades CS, Poulaki V, Chauhan D, Fanourakis G, Gu X et al. Molecular sequelae of proteasome inhibition in human multiple myeloma cells. Proc Natl Acad Sci USA 2002; 99: 14374-14379.

26. Mitsiades N, Mitsiades CS, Poulaki V, Chauhan D, Richardson PG, Hideshima T et al. Biologic sequelae of nuclear factor-kappaB blockade in multiple myeloma: therapeutic applications. Blood 2002; 99: 4079-4086.

27. Hideshima T, Chauhan D, Richardson P, Mitsiades C, Mitsiades N, Hayashi T et al. NF-kappa B as a therapeutic target in multiple myeloma. J Biol Chem 2002; 277: 16639-16647.

28. Filella X, Blade J, Guillermo AL, Molina R, Rozman C, Ballesta AM. Cytokines (IL-6, TNFalpha, IL-1alpha) and soluble interleukin-2 receptor as serum tumor markers in multiple myeloma. Cancer Detect Prev 1996; 20: 52-56. 
29. Jurisic V, Colovic M. Correlation of sera TNF-alpha with percentage of bone marrow plasma cells, LDH, beta2-microglobulin, and clinical stage in multiple myeloma. Med Oncol 2002; 19: 133-139.

30. Lichtenstein A, Berenson J, Norman D, Chang MP, Carlile A. Production of cytokines by bone marrow cells obtained from patients with multiple myeloma. Blood 1989; 74: 1266-1273.

31. Neben K, Mytilineos J, Moehler TM, Preiss A, Kraemer A, Ho AD et al. Polymorphisms of the tumor necrosis factor-alpha gene promoter predict for outcome after thalidomide therapy in relapsed and refractory multiple myeloma. Blood 2002; 100: 2263-2265.

32. Usnarska-Zubkiewicz L. Level of interleukin-6 (IL-6), soluble interleukin-6 receptors (slL-6R) and tumor necrosis factor alpha (TNF-alpha) in untreated and progressing multiple myeloma. Pol Arch Med Wewn 1998; 99: 30-37.

33. Brown EE, Lan Q, Zheng T, Zhang Y, Wang SS, Hoar-Zahm S et al. Common variants in genes that mediate immunity and risk of multiple myeloma. Int J Cancer 2007; 120: 2715-2722.

34. Davies FE, Rollinson SJ, Rawstron AC, Roman E, Richards S, Drayson M et al. Highproducer haplotypes of tumor necrosis factor alpha and lymphotoxin alpha are associated with an increased risk of myeloma and have an improved progression-free survival after treatment. J Clin Oncol 2000; 18: 2843-2851.

35. Du J, Yuan Z, Zhang C, Fu W, Jiang H, Chen B et al. Role of the TNF-alpha promoter polymorphisms for development of multiple myeloma and clinical outcome in thalidomide plus dexamethasone. Leuk Res 2010; 34: 1453-1458.

36. Kadar K, Kovacs M, Karadi I, Melegh B, Pocsai Z, Mikala G et al. Polymorphisms of TNF-alpha and LT-alpha genes in multiple myeloma. Leuk Res 2008; 32: 1499-1504.

37. Morgan GJ, Adamson PJ, Mensah FK, Spink CF, Law GR, Keen LJ et al. Haplotypes in the tumour necrosis factor region and myeloma. Br J Haematol 2005; 129: 358-365.

38. Zheng C, Huang DR, Bergenbrant S, Sundblad A, Osterborg A, Bjorkholm M et al. Interleukin 6, tumour necrosis factor alpha, interleukin 1beta and interleukin 1 receptor antagonist promoter or coding gene polymorphisms in multiple myeloma. $\mathrm{Br} \mathrm{J}$ Haematol 2000; 109: 39-45.

39. Tsimberidou AM, Waddelow T, Kantarjian HM, Albitar M, Giles FJ. Pilot study of recombinant human soluble tumor necrosis factor (TNF) receptor (p75) fusion protein (TNFR:Fc; Enbrel) in patients with refractory multiple myeloma: increase in plasma TNF alpha levels during treatment. Leuk Res 2003; 27: 375-380.

40. Kast RE. Evidence of a mechanism by which etanercept increased TNF-alpha in multiple myeloma: new insights into the biology of TNF-alpha giving new treatment opportunitiesthe role of bupropion. Leuk Res 2005; 29: 1459-1463.
41. Basseres DS, Baldwin AS. Nuclear factor-kappaB and inhibitor of kappaB kinase pathways in oncogenic initiation and progression. Oncogene 2006; 25 6817-6830.

42. Chan H, Bartos DP, Owen-Schaub LB. Activation-dependent transcriptional regulation of the human Fas promoter requires NF-kappaB p50-p65 recruitment. Mol Cell Biol 1999; 19: 2098-2108.

43. Kreuz $S$, Siegmund D, Scheurich $P$, Wajant $H$. NF-kappaB inducers upregulate cFLIP, a cycloheximide-sensitive inhibitor of death receptor signaling. Mol Cell Biol 2001; 21: 3964-3973.

44. Kuhnel F, Zender L, Paul Y, Tietze MK, Trautwein C, Manns M et al. NFkappaB mediates apoptosis through transcriptional activation of Fas (CD95) in adenoviral hepatitis. J Biol Chem 2000; 275: 6421-6427.

45. Mendoza FJ, Ishdorj G, Hu X, Gibson SB. Death receptor-4 (DR4) expression is regulated by transcription factor NF-kappaB in response to etoposide treatment. Apoptosis 2008; 13: 756-770.

46. Micheau O, Lens S, Gaide O, Alevizopoulos K, Tschopp J. NF-kappaB signals induce the expression of c-FLIP. Mol Cell Biol 2001; 21: 5299-5305.

47. Shetty S, Graham BA, Brown JG, Hu X, Vegh-Yarema N, Harding G et al. Transcription factor NF-kappaB differentially regulates death receptor 5 expression involving histone deacetylase 1. Mol Cell Biol 2005; 25: 5404-5416.

48. Borset M, Hjorth-Hansen H, Johnsen AC, Seidel C, Waage A, Espevik T et al. Apoptosis, proliferation and NF-kappaB activation induced by agonistic Fas antibodies in the human myeloma cell line $\mathrm{OH}-2$ : amplification of Fas-mediated apoptosis by tumor necrosis factor. Eur J Haematol 1999; 63: 345-353.

49. Klapproth K, Sander S, Marinkovic D, Baumann B, Wirth T. The IKK2 NF-\{kappa\}B pathway suppresses MYC-induced lymphomagenesis. Blood 2009; 114: 2448-2458.

Cell Death and Disease is an open-access journal published by Nature Publishing Group. This work is licensed under the Creative Commons Attribution-Noncommercial-No Derivative Works 3.0 Unported License. To view a copy of this license, visit http://creativecommons.org/licenses/by-nc-nd/3.0/ 